\title{
The economics of international migration: A short history of the debate
}

\author{
Timothy J. Hatton * \\ University of Essex, UK \\ Australian National University, Australia
}

\section{A R T I C L E I N F O}

\section{Article history:}

Received 20 August 2013

Received in revised form 19 May 2014

Accepted 21 May 2014

Available online 18 June 2014

JEL classification:

B21

F22

Keywords:

Economics of international migration

\begin{abstract}
A B S T R A C T
This paper provides a view of progress over the last quarter century in the economics of international migration. I focus on two long established topics and two that have surged in the last decade. Interest in immigrant and assimilation and in the labour market effects of immigration has been kept going by methodological debates and by the diffusion of empirical work from the United States to the wider world. More recently, the difficult politics of immigration policy has fuelled the research agenda and has given rise to a new literature on the forces that drive immigration policy and on the assessment of its effects. Important also is the growth of interest in the causes and consequences of emigration from developing countries. Most notable has been the revival of interest in the brain drain and the wider consequences of the expanding emigrant diaspora.
\end{abstract}

(c) 2014 Elsevier B.V. All rights reserved.

\section{Introduction}

The last quarter of a century has seen a flowering of research on migration and immigration. A large empirical edifice has been constructed on a relatively slender theoretical base. And while some topics have faded in importance, others have more than made up for it. The original topics include immigrant assimilation and the impact of immigration on the earnings of non-immigrant workers. The debate on these topics has been kept alive by three things. First, although we have learned a lot, some of the key empirical issues are still unresolved and this had led to ongoing refinement of models, methods and data. Second, studies for the United States (and other settler countries) have been transposed to a widening range of other countries and settings. In Europe this has been fostered by the rapid growth of immigration itself. Third, immigration has been, and still is, a hot political topic. In some cases it has led to a polarization of academics into pro- and anti-immigration camps, and this has added heat, and occasionally light, to the academic debate.

From the late 1990s, it is possible to discern several new waves in the focus and direction of research. Economists have explored dimensions of migration that were previously neglected or that were the domain of other social sciences. Here I focus on two clusters of activity. The first is immigration policy, which includes the analysis of public opinion and the link with policy formation. It also includes the analysis of the effects of policy on the volume and direction of migration and the

\footnotetext{
An earlier version of this paper was presented at the 25th annual Conference of the European Association of Labour Economists, Torino, Italy, 19-21 September 2013. I am very grateful to Alessandra Venturini and Joop Hartog for useful and constructive comments.

* Department of Economics, University of Essex, Wivenhoe Park, Colchester CO4 3SQ, UK. Tel.: + 441206 872182; fax: + 441206872724 .

E-mail address: hatton@essex.ac.uk
}

characteristics of migrants. A second trend is the growing focus on emigration rather than immigration and on source countries rather than on the destination. This has seen a proliferation of studies on topics as diverse as remittances and refugee movements. But perhaps most prominent is the renewed focus on the brain drain and more generally the consequences of emigration for poor source countries. In choosing to focus on these areas I omit much of the ever widening scope of migration analysis and I make no attempt to be comprehensive.

\section{The traditional issues: Assimilation and impact}

\subsection{The economic assimilation of immigrants}

The first issue is immigrant assimilation-the speed and degree to which immigrants catch up with the native born in earnings employment and in other dimensions. The modern literature started with the seminal paper by Barry Chiswick (1978) showing strong wage assimilation for immigrants in the United States. Borjas $(1985,1995)$ pointed out that if successive cohorts differ in their labour market "quality" then a cross-sectional estimate would be a misleading guide to the experience of any given cohort. The specific focus was the apparent downward shift in the earnings functions of immigrants relative to natives in the United States from around 1970 until the 1990s. Its proximate cause was the shift in the sources of US immigration away from Western Europe and towards poorer countries in Latin America and Asia. Two key findings emerged from this debate. The first is that immigrants do assimilate even if they don't catch up with natives in a single generation. Studies of immigrants in a range of countries support this view, with one important caveat. For most destination countries immigrant assimilation is stronger in employment rates and weaker in wage rates than 
for the United States. Second, there are large differences in the labour market performance of immigrants by source country, even controlling for observables such as education; in general, the poorer the source country the poorer the performance.

The literature on assimilation has spawned two important strands. The first is to discover what initial disadvantages immigrants suffer and how these obstacles are overcome. The most important feature to emerge is proficiency in the host country language. Language proficiency has a sizeable effect on earnings (up to $40 \%$ ), especially when account is taken of endogeneity and measurement error (Chiswick and Miller, 1995; Dustmann and van Soest, 2001). The acquisition of host country skills and education is highly contingent on language proficiency. Also important is access to immigrant networks (Munshi, 2003). A striking feature of the assimilation literature is that it gets away from an older tradition that consigned all unmeasured differences in immigrant and native earnings to 'discrimination'-a concept that Oaxaca decompositions cannot illuminate. But the cost is a lack of social context: immigrants are seen as assimilating as atomistic individuals in an anonymous soup called the host country labour market. While sociologists have embraced the idea that outcomes for immigrants depend in large part on the 'context of reception' in the host society, economists are yet to take this very seriously.

One thread of the literature that goes part of the way delves into the effects of ethnic concentration (or ghettos) on the assimilation process. If there is discrimination against immigrants in the wider community then individuals may gain by remaining within the ethic community, something that may be enhanced by specialisation in ethnic goods. On the other hand ethnic communities may involve crowding externalities, negative peer group effects and reduced opportunities for profitable trade. Hence the effects of ethnic concentrations on immigrant outcomes could go either way and the results may differ across ethnic groups and with the characteristics of the individual immigrant. ${ }^{1}$ Borjas (1992) finds that the income, education and occupational prestige of second-generation immigrants are inherited partly from their parents and partly, as an ethnic capital externality, from the ethnic group as a whole. The results suggest that there is considerable persistence in performance from one generation to the next, much of it arising from the transmission of ethnic capital (see also Card, 2005).

This strand of assimilation literature has increasingly moved into the territory long occupied by sociologists (see Alba and Nee, 1997). For example, one line of enquiry looks at ethnic identity and the degree to which ethnic minority immigrants choose to define themselves outside (or even in opposition to) the mainstream culture. Overall the evidence suggests that maintaining a distinct ethnic identity is not an impediment for education and employment among those who also embrace the mainstream culture (Casey and Dustmann, 2010; Constant and Zimmermann, 2008). The literature also extends to issues such as civic and political participation, intermarriage and fertility behaviour, health and life satisfaction. And it increasingly treats such variables as outcomes of interest in their own right, rather than as intermediate variables to explain wages or employment. Thus what was becoming a somewhat stale literature has been reinvigorated and broadened by shifting the focus into other disciplinary domains.

The second development stemming from the literature on assimilation is self-selection. Borjas (1987) developed a version of the Roy model to show that immigrants could be positively or negatively selected from the source country population depending on the conditions they face. If the return to skill is higher at home than at the destination, then immigrants will tend to be negatively self-selected on the skills that are rewarded by the labour market. Thus immigrants do not have to be positively selected as is (or was) routinely assumed. The

\footnotetext{
1 A number of studies have addressed the endogeneity issue that arises from migration across localities. Those that choose to migrate away from the ghetto may have superior characteristics and hence the measured effect of ethnic concentration may be partly due to self-selection.
}

implication is that migrants from countries that are poor and unequal relative to the destination are more likely to be negatively selected. However this neglects the costs of immigration. If the costs vary less than in proportion to earnings then this will offset negative selection by making migration less attractive to the low skilled.

The Roy model has been at the heart of a large number of empirical studies. While it was originally invoked to explain the performance of immigrants in the host labour market, attention subsequently turned towards more direct assessments of self-selection into emigration from the origin country. Again the initial focus has been on immigration to the United States, especially from Mexico. Following Chiquiar and Hanson (2005) a number of studies have compared the characteristics of immigrants with non-immigrants in the source country. Broadly speaking the results suggest that immigrants are drawn disproportionately from the middle of the distribution of education and wages. That would be consistent with higher returns to education attenuating migration from the top of the distribution while higher fixed costs attenuate migration from the bottom. But this leaves aside many other influences on migrant selection, such as pre-existing migrant networks and differences in the incentive to emigrate from rural and urban areas. One of the most important costs is that imposed by immigration policy. Although illegal migration from Mexico to the US is feasible, it is still costly. In the case of Puerto Rico (which is poor and unequal) there are no such barriers and the evidence suggests that migrants to the US are negatively selected while return migrants are positively selected (Borjas, 2008).

Migrants from Mexico and Puerto Rico to the United States are unlikely to be typical; most international migrants face higher policy hurdles and greater costs of migration. Data on the migrant stock in OECD countries from a range of developing countries indicates that those migrants have much higher average levels of education than the source country populations from which they were drawn. Some of this reflects education acquired post-migration but the evidence from surveys of migrant intentions indicates that those with more education are more likely to plan to emigrate. Yet as most of the source counties are poor and unequal relative to the potential destinations that should mean strongly negative selection. One explanation is that potential migrants respond to absolute income gaps, which are larger for the more skilled, rather than relative gaps, which are larger for the unskilled (Grogger and Hanson, 2011). This can explain both the selection from a given source country and the sorting across destinations but it is inconsistent with concave utility. Alternatively positive selection from poor countries may reflect severe poverty constraints (Belot and Hatton, 2012), although their precise nature is hard to identify. ${ }^{2}$ As noted further below, those constraints might be made tighter by skill selective policies, but looser by family reunification policies (for those fortunate enough to have relatives at the destination).

The literature on immigrant assimilation has endured by becoming broader and deeper. It has broadened as researchers have applied the methods developed in the United States to a wider array of countries and settings, and as the concept of what we mean by assimilation has expanded into the social sphere. Richer datasets have helped make this possible and allowed the assessments to include return and circular migration. At the same time the slender theoretical foundation upon which the original assimilation models were built has been elaborated and increasingly refocused on the migration decision and on conditions in countries of origin. These shifts in the research agenda have kept alive a literature that might otherwise have gone into decline.

\subsection{The labour market impact of Immigration}

In the standard partial equilibrium labour market model, with a downward sloping labour demand curve, an immigration-induced increase in labour supply should reduce the average wage and shift the

\footnotetext{
2 One reason for thinking that capital market failure is important is the difficulty of providing collateral for a loan, the purpose of which is to leave the country.
} 
income distribution in favour of profits. Alternatively, if wages are sticky then, to the extent that immigrants find jobs, they reduce native-born employment. With few exceptions the first round of studies suggested that the wage or employment effects of immigration are close to zero. An analysis of 18 studies found that the average effect on natives of a one percent increase in the migrant share of the labour force was to depress the native wage by just $0.11 \%$ (Longhi et al, 2005). Such results seem inconsistent with the usual elasticities of labour demand of around -0.3 to -0.5 and they cast doubt on the standard framework that underpins much of the political economy of immigration. But most of these studies sought to isolate the effects of immigration by correlating wage or employment rate changes with immigrant inflows across localities within the receiving country. If the effects of immigration to a locality are somehow diffused across the wider economy then the so-called spatial correlations approach will underestimate the true national effects.

Much of the debate has focused on accounting for, and overcoming, the potential biases in the spatial correlations approach. One concern is that immigrants locate in booming regions, and a variety of methods have been used to account for this endogeneity. More important is the possibility that immigration to a locality displaces the some of the native-born and previous immigrants to other localities. The debate was initially stimulated by the apparent absence of any native employment or wage effects following the Mariel boatlift that brought 125,000 Cubans to Miami in 1980, adding about 7\% to its labour force (Card, 1990). In order to test whether such results are generalizable subsequent studies modelled the mobility of the native-born in response to a local immigration shock. The results were mixed but displacement effects were often found to be small and sometimes even perverse. To give one example, Card (2001) found no effect of immigration on a cross section of changes in the labour force across US cities in 1985-90. Further studies using different variable definitions and employing differencesin-differences methodology came to largely the same conclusion. One particular issue is that, for most local labour markets, the contribution of immigration is small as compared with other influences and so inference is difficult. Yet, taken at face value, these results simply deepen the puzzle: if the wage effects of immigration are modest then displacement effects should be large, but they are not.

Another possibility is that the local demand for labour is indeed highly elastic as a result of inter-regional trade (Rybczynski effects) and/or capital flows. But at the national level labour demand would likely be less elastic and the wage effect of immigration accordingly greater. Some evidence on the national effects of immigration comes from immigration shocks. One is the repatriation of the Algerian pieds noirs to France in 1962 (Hunt, 1992); another is the retornados from Angola and Mozambique to Portugal in 1994-6 (Carrington and di Lima, 1996). These immigration shocks seem to have substantially reduced average wages despite being interpreted to the contrary, and they deserve further scrutiny. Another 'natural experiment' is provided by the influx of Russian Jews to Israel when the Soviet Union lifted its restrictions on emigration late in 1989. Again, the wage effects seem to have been more negative than some would suggest (Hatton and Williamson, 2005, pp. 299-302).

In his landmark study Borjas (2003) sought to sidestep the puzzles raised by spatial correlations by analysing the impact of immigration by 32 education/experience groups at the national level in the US for the census years 1970 to 2000 . The idea is that there is less scope for mobility across education and experience groups than there is between cities or regions. He concluded that the labour demand curve is indeed downward sloping with an elasticity of about -0.3 to -0.4 . Allowing some substitutability between age/experience groups, the effect of immigration over the 1980s and 1990s was to reduce native wage by $8.9 \%$ for high school dropouts and by 3.2\% overall (Borjas, 2003, p. 1369). Applying the same methodology at the state level suggested much smaller wage effects, implying larger displacement effects than the previous literature suggested (Borjas, 2003, 2006).
The specification that delivered these results has been challenged on several grounds. The most important is that within each education/ experience group immigrants and natives may be imperfect substitutes. ${ }^{3}$ Ottaviano and Peri (2012) find that even with relatively high within-group substitutability the effects of immigration on native wages are attenuated and the effect on the wage of previous immigrant cohorts is magnified (see also Manacorda et al., 2012). Perhaps the latter is not surprising as immigrants are a relatively small share of the labour market. But it does raise the question of why immigrants and natives with similar observable characteristics are less than perfect substitutes. One possible answer to this is that immigrants' task-specific skill sets differ from those of natives (Peri and Sparber, 2009). Another is that those from countries with weak education systems have fewer skills than their qualifications would suggest (Coulombe and Tremblay, 2009; Mattoo et al, 2008) and so the relevant competitor group is not natives with the same observable skills. Even with the same skill levels, differences could arise because immigrants at early stages in the process of assimilation are placed lower in the wage distribution than their true skills warrant (Dustmann et al., 2012). Interestingly, it is only recently that researchers have drawn what now seem obvious links between the labour market effects of immigration and the assimilation literature.

These links are a little stronger in another branch of the recent literature: the fiscal impacts of immigration. Do immigrants pay more in taxes than they take out in benefits and public services? This is an important issue that shapes perceptions and policies towards immigrants. The net fiscal contribution of immigrants depends on whether it is calculated at a point in time or over the lifecycle, and on which taxes and benefits are included. But outcomes are chiefly driven by two interacting factors. One is that those with more than high school education generally make a net contribution while those with lower skills impose a net cost (Smith and Edmonston, 1997; Storesletten, 2000). The other is that the more generous is the welfare state and the less flexible is the labour market the greater is the net fiscal burden imposed by lowskilled immigrants (Boeri, 2010; Storesletten, 2003). Thus the fiscal costs are a particular concern for some European countries where, over the last 30 years, the welfare state has expanded and the labour market performance of immigrants has deteriorated.

There are, of course, many other effects of immigration. At the macro level these have been widely analysed in general equilibrium models with neoclassical trade-theoretic foundations. These models have become increasingly sophisticated (useful surveys are Drinkwater et al, 2003; Trefler, 1998), but three points are worth making. First, until recently, the calibrations used in such models have largely ignored the empirical findings of immigration economists. Second the wider effects operating through trade, capital flows and the public sector can easily swamp the partial equilibrium labour market effects. And third, the general equilibrium setting focuses attention not only on the distributional effects but also on the overall immigration surplus. Ironically, the labour market literature, which is generally pro-immigration, has focused largely on the absence of losses for the potential losers rather than stressing the scale of benefits for the gainers.

By contrast with the assimilation literature, assessments of the impact of immigration have remained firmly in the economic sphere. The debate initially expanded to a wider range of countries but methodological issues have played an increasing role. This is because first generation studies produced results that seem incompatible with standard economic analysis. Fuelled by the ongoing policy debate, attention has increasingly shifted towards the fiscal effects of immigration, where methodological issues are yet to become a central focus. This combination of policy relevance and lack of academic consensus will continue to stimulate the quest for a more comprehensive and internally consistent account of migration's economic impact.

\footnotetext{
${ }^{3}$ Another critique is that the estimating equations incorporate a negative bias (Peri and Sparber, 2011).
} 


\section{Immigration policy: Causes and effects}

\subsection{Explaining immigration policies}

Policy formation is central to the immigration debate, yet until recently, it has been largely the domain of political science rather that economics. The standard partial equilibrium model tells us why we might expect immigration policy to be restrictive. If workers outnumber the owners of capital at the ballot box then the median voter will oppose immigration. ${ }^{4}$ Thus the puzzle is not why immigration policy in developed countries is so restrictive, but rather, why it is not even more restrictive. Benhabib (1996) showed that if workers bring some capital or human capital with them then the constituency that opposes immigration depends on whether immigration increases or reduces the capital-labour ratio. If immigration is unskilled then a coalition of capitalists and skilled workers could form a majority in favour of immigration.

An obvious place to start is with public opinion. It has long been known that the majority of voters in most countries oppose immigration. The question is why. A number of studies have set out to test what we might call the factor-proportions version of public opinion. The universal finding from the many datasets that are now available is that the less educated the individual the more anti-immigration he or she is likely to be. This was originally interpreted as reflecting the individual's labour market position: if immigrants are unskilled then the skilled have less to fear (O'Rourke and Sinnott, 2006; Scheve and Slaughter, 2001). Studies of immigration opinion have also found that concerns about the fiscal costs weigh heavily with some citizens (Boeri, 2010; Facchini and Mayda, 2009). One piece of evidence is that while pro-immigration attitudes are positively related to education, reflecting labour market competition, conditional on this, they are negatively related to income, reflecting concerns about the tax implications of immigrant welfare dependency. This helps to explain why attitudes are sometimes negative even among those higher up the scale of class, education and income.

Political scientists, for whom the study of attitudes has a longer history, take a rather different view. For example Hainmueller and Hiscox $(2007,2010)$ argue that if labour market competition is the issue then individuals should be more negative towards immigrants with their own skill level. But they are not; both the highly educated and the less educated are more favourable to high-skilled immigration. Rather, they find that the more educated have greater tolerance towards minorities and are more positive about ethnic and cultural diversity, and this explains two thirds of the gradient between attitudes and education. Other evidence suggests that attitudes are typically more negative towards ethnic and religious minorities (Dustmann and Preston, 2007). A large literature also finds that anti-immigrant attitudes are associated with racism, nationalism and ethnocentrism, although regressing one attitude on another leaves the causal mechanisms rather unclear (but see Card et al., 2012). Such attitudes are also associated with selfassignment on the right of the political spectrum and with membership of far right political parties (Kessler and Freeman, 2005).

One rather neglected issue is the effect of migration itself on attitudes. Survey evidence indicates that individuals have very little idea of the true scale of immigration. Yet there is some broad correspondence across countries between immigration and negative attitudes (Lahav, 2004). But the cross-country evidence is rather ambiguous and there is an obvious issue of reverse causation (negative attitudes lead to restrictive policies which lower immigration). There is, however, a tradition of research on whether the individual's contact with immigrants, and especially neighbourhood ethnic minority concentrations, leads to more positive or more negative attitudes. Taking account of self-selection across locations (sometimes called white-flight) indicates

\footnotetext{
${ }^{4}$ Even though the total gain to capitalists exceeds the total loss to workers (there is a net immigration surplus).
}

that this effect is negative, at least for Britain (Dustmann and Preston, 2001). That raises a much wider question about the design of public policies that influence ethnic minority concentrations.

The analysis of public opinion has been illuminating but there remains a vast chasm between people's attitudes and the immigration policies pursued by their elected representatives. So, why are immigration policies less restrictive than what people actually want? One view is that immigration politics in liberal democracies is characterised by an 'expansionary bias' (Freeman, 1995). The main reason for this is that anti-immigration sentiment is diffuse while pro-immigration sentiment is concentrated. In Freeman's terms immigration is dominated by clientilist politics; in simple terms capitalists are well organised and they have economic and political clout. In an important paper, Facchini et al. (2011) show that business groups in the United States have invested substantial resources in lobbying for sector-specific visa allocations in temporary worker programmes. The evidence suggests that this activity is successful although it is often opposed by organised labour. The strength of industry lobbies and the weakness of unions could explain why immigration policies have remained more open in the United States than in other countries and why this gap has narrowed in recent decades. Such hypotheses are yet to be fully tested.

A different perspective is to compare immigration policy with policy on international trade. While opinion favouring restricting imports is somewhat weaker than that on restricting immigration, trade has been liberalised by orders of magnitude more than migration. One argument is that, unlike international trade, immigration has a social dimension, which makes it much more politically contested territory (Greenaway and Nelson, 2006). Here the pro-immigration pressure groups range from ethnic minority interests to those concerned with civil rights and humanitarian issues; these are counterbalanced by nativist and nationalist lobbies as well as by the economic concerns previously mentioned. This perhaps explains why in OECD countries as a whole the main modes of admission are family reunification and refugees, with less than a quarter entering through the employment channel. In addition, unlike international trade, immigration inflows to developed countries are not broadly balanced by outflows. Thus, there is no powerful economic interest group (analogous to exporters in international trade) that is vigorously lobbying governments to strike deals for access to foreign labour markets in exchange for lower barriers to immigration. This is an important reason why we see multilateral agreements, based on reciprocity, for international trade but not for international migration (Hatton, 2007).

As noted earlier, economists are latecomers to the analysis of immigration attitudes and policy and they have come to grips only partially with the longer standing debates in political science. While some progress has been made there are two key lacunae. One is that the cross sectional analysis of attitudes tells us how composition affects attitudes, not how attitudes are formed and changed over time. The other is the vexed issue of how attitudes and other variables drive shifts in policy. It seems that there is more to be learned from political science.

\subsection{Immigration flows and immigration policy}

Immigration policy is a system of rationing; it differs from trade policy where tariffs raise the price of entry and are therefore more easily incorporated into economic models. If the quantity constraint is binding then the scale and composition of immigration should depend only on the structure of immigration policies. Yet recent studies have shown that source-country economic and demographic forces still matter. Some studies have examined the patterns of immigration from a range of source countries to a single destination. One study for immigration to the United States finds that income gaps, inequality, source country demographics all influenced the flow of immigrants from different source countries (Clark et al., 2007). Several studies have modelled the immigration flows by source country to a set of OECD destinations, stressing the importance of host country variables such as GDP per 
capita and measures of welfare state generosity. But the most important finding is that the volume of migration to a destination from a particular source country is conditioned by proximity, by cultural and language affinities and above all by past migration as reflected in the stock of previous immigrants (for a recent example, see Adsera and Pytlikova, 2012).

Why do economic forces matter so much? One reason is that immigration policy is not the strict rationing system that is sometimes envisaged. Most countries set multiple criteria for entry, which may be adjusted according to domestic economic conditions, rather than fixing an overall quota. This is especially so for family reunification and refugee streams, which represent the bulk of all immigration. Another reason is that some economic and demographic variables that appear in the regressions represent a mix of incentive and policy. One example is the often powerful effect of migrant stock in the destination country. This captures the effect of networks on the incentive to migrate from a given source country but it also reflects the degree to which family reunification policy permits it. Nevertheless, policy shifts should matter, and several studies find discernible, if modest, effects for dummy variables representing identifiable policy changes.

One of the biggest challenges has been to somehow characterise subtle and complex immigration policies in the form of index numbers, something that recent studies have attempted to do (Mayda, 2010; Ortega and Peri, 2012). For rich destination countries the average tightening of entry laws reduced immigration by about 6\% (Ortega and Peri, 2012). But different branches of policy will have different effects, partly because there is no common metric. One important distinction is between policies that determine entry and those that determine the ability to stay. Another dimension is characterising policy relating to different immigrant streams. For example policy towards asylum seekers is very different from that of other branches of immigration policy, because of differences in underlying motivations and in the legal framework. One attempt to assess the effects of policy on asylum applications to a set of OECD countries finds that tougher refugee status determination procedures and tighter border controls reduce asylum applications while the living conditions that asylum seekers face after arrival have very little effect (Hatton, 2009).

As most countries apparently want to raise the proportion of their immigrants that is highly skilled, not least because of concerns about the fiscal costs, it would be useful to know more about the effects of skill-selective policies. Here the data constraints are even more severe and much of the focus has been on immigrant stocks (or changes in stocks) rather than on flows. Several studies have examined the effects of skill selection, often as dummies for countries that have points systems. While such measures could be (and are being) improved, it is doubtful that tweaking the skill requirements in what are already selective employment streams will have more than marginal effects. More important would be altering the composition of immigration streams. In 2010 employment stream immigrants accounted for just $21 \%$ of permanent immigrants to the OECD, as compared with $20 \%$ admitted through free movement and $36 \%$ though family reunification (OECD, 2012, Table I.4). Despite the dominance of family reunification, migration is still typically modelled as if it were exclusively a labour market decision. Studies that disaggregate immigration streams or that focus more directly on family reunification are still remarkably rare.

The debate on the impact of immigration policy is an area that has been stimulated by controversies over policy. One example is the construction of forecasts about the effects of policy change. But progress has been limited and has been severely constrained by lack of appropriate data. That constraint is being eased as more refined measures of policy become available. But there is also a need to better understand the source country constraints, how migration streams start and persist, and above all to bring the analysis of family reunification and humanitarian migration to centre stage. It seems likely that this will provide a rich ongoing research agenda.

\section{Emigration and the source country}

\subsection{Brain drain or brain gain?}

One of the most important themes in recent research is the likely effects of South-North migration on conditions in the source countries. Most notable of all is the revival of interest in the brain drain, a topic that went into quiescence after a flurry of activity in the 1960s and 1970s. This renewed activity has been driven by two factors. The first is the development of models which suggest that the selective emigration of the high-skilled and high-educated could stimulate the acquisition of education in poor source countries, creating a brain gain that could counterbalance the original brain drain (e.g. Mountford, 1997; Stark et al., 1997). The other cathartic influence is the development of far richer and more comprehensive datasets than were previously available. Particularly important is the database produced by Docquier and Marfouk (2006) and its subsequent refinements, which has formed the basis for most of the recent studies. These data are census-based estimates for the stock of adult immigrants in each OECD country by source country, by education and by gender.

So how big is the brain drain? For most of the world's poorer countries the brain drain is not particularly large. For the world as a whole the emigration rate for the college educated is only slightly higher than the rate for those with less than college education. It is most severe for those countries in the low and middle income group, that are relatively small (populations of less than 10 million) and are situated close to rich potential destinations. As of 2001 more than four fifths of those with tertiary education born in Guyana, Jamaica and Haiti had emigrated, and the rates also exceed $50 \%$ for a number of countries in subSaharan Africa. Perhaps even more important are the high rates of emigration in key professions such as doctors and nurses from Africa and engineers and IT specialists from India (Docquier and Rapoport, 2012, p. 688). But contrary to popular opinion the brain drain is not getting worse. Except in sub-Saharan Africa and Central America, source country education has largely kept pace with high skilled emigration (Docquier and Rapoport, 2012, p. 689).

How has the brain drain affected the stock of skills in source countries? In the absence of a positive educational response to emigration the outcome would be negative, as the older literature assumed. By increasing the scarcity and hence the return on skills at home emigration could induce a compensating response but replacement would only be partial. However, the mechanism invoked by the more recent literature is that the prospect of emigration raises the expected return to emigration, inducing a supply response. Ex post some of the high-skilled do not emigrate and so it is an empirical question whether the additional skills generated outweighs the loss through emigration. In their pioneering papers Beine et al. (2001) and Beine et al. (2008) found that a doubling of the emigration rate induces an increase of $5 \%$ in the acquisition of tertiary education. As a result the majority of developing countries experience a net brain gain. The countries least likely to experience a net brain gain are those with high emigration rates and high initial levels of human capital. These include some of the countries of sub-Saharan Africa, Central America the Caribbean and especially small island states.

These results cast important new light on the brain drain. Although they appear to be robust they are based on aggregate data for migrant stocks, so that the precise underlying channels are not identified. Is it really true that the prospect of emigration stimulates education even for those who don't emigrate ex post? Surveys of emigrant intentions support this view: far more people express some intention to emigrate than actually do emigrate (Gibson and McKenzie, 2012; Van Dalen et al., 2005). A recent wave of research has investigated the underlying mechanisms at a more micro level. Examining survey data for the Cape Verde islands, Batista et al. (2012) find that the attainment of intermediate secondary schooling is strongly positively related to the individual's probability of future emigration. In a study of Fiji Chand and Clemens (2008) find that exogenous regime change increased the incentives 
for Indians to emigrate and led to a surge in tertiary enrolment. These and other studies are for countries for which the aggregate data suggests that the brain drain outweighs the brain gain, and it would be interesting to know if similar results apply to countries with more modest high-skill emigration rates.

A large proportion of high educated migrants received part of their education in the host country. Migration for education, particularly higher education, is increasingly important. Given that foreign students are a major source of income for universities in developed countries, it is surprising that student migration has only recently gained the attention of academic economists. One implication is that the source country educational response will be focused on the higher school and lower university qualifications that provide access to more advanced study. Another is that the incidence of emigration is likely related to student achievement at home; if students are counted as migrants this would reinforce positive selection. Whether, in the long run, this adds significantly to the brain drain depends on whether they return to the home country. Estimates of return rates vary widely but they appear to be lower the higher the qualification and especially so for qualifications in subjects like science, engineering and medicine.

Return migration is an obvious source of brain gain, whether skills were acquired at home or abroad. The evidence suggests that between 20 and $50 \%$ of immigrants return within five years (OECD, 2008) and that return (and sometimes circular) migration has been on the increase. One important implication is that gross flows will be a misleading guide to the current scale of the brain drain if a large proportion of the skilled return. The focus of earlier research was on whether return migrants were positively or negatively selected in accordance with the predictions of the Roy model (Borjas and Bratsberg, 1996). The typical finding was that returnees were negatively selected from the original emigrants (though not necessarily from the source population). More recently the focus has been on modelling return migration in a lifecycle context together with saving and human capital accumulation (Dustmann, 1997; Dustmann et al., 2011; Mayr and Peri, 2009). Even if returnees are negatively selected from among migrants they may have gained skills that they would not otherwise have acquired. The literature on the wage and productivity gains of return migrants gives conflicting results. Perhaps this is not surprising given the differences in policy and in incentives produced by different combinations of origin and destination countries.

Research on the brain drain has seen a remarkable renaissance. This is a clear case where a latent interest in the topic has been unleashed by new and better data. This has involved assembling data specifically for the purpose rather than simply staying within the confines of existing surveys collected for other purposes, as with much of the microeconometric literature. It has also stimulated some rethinking of the theoretical framework that dominated the earlier literature. We may be relieved that the negative effects on developing countries are less severe than was once thought, and perhaps for this reason less attention has been paid to policy implications. But the light of the evident demand for student migration it would be worth revising or replacing old policy ideas, such as the Bhagwati tax.

\subsection{The effects of diaspora}

What are the economic effects of an emigrant diaspora? Estimates of the worldwide gains from completely eliminating barriers to migration range from around one half to one and a half times global GDP (Clemens, 2011, p. 86). Such estimates are based on (increasingly sophisticated) general equilibrium models, in which migration equalises wages around the world. One implication is massive and implausible emigration rates: upwards of half the population of non-OECD countries would need to emigrate. But much more modest increases would generate global gains that exceed those of eliminating all remaining trade barriers. It is important also to recognise that most of the gains accrue to the migrants themselves, and especially those moving from the poorest to the richest countries. A series of studies have sought to estimate migrant gains at the margin, allowing also for the non-random selection of emigrants. According to one study, potential emigrants from the Philippines to the United States could increase their income by a factor of 3.5, those from Haiti by 7.8 and those from Nigeria by 8.4 (Clemens et al., 2008).

Even though these gains are likely to outweigh source country losses there is, nevertheless, an ongoing concern for the effects on those left behind (for a useful survey, see Lodigiani, 2009). An obvious parallel with the destination country literature would be to look at the effects on wages, but surprisingly few papers have done this. One study applying the Borjas (2003) methodology to Mexico finds that the effect of emigration in the 1990s alone was to raise the relative wage of high school graduates by $4 \%$ and the wage of those with college education by 3\% (Mishra, 2007, p. 193). Another parallel is the possible fiscal cost. Some of the older studies focused particularly on the cost to source country taxpayers of educating those that subsequently emigrated (Bhagwati and Hamada, 1974). But there are surprisingly few estimates, even of the direct fiscal costs. One estimate for Indians who migrated to the US between 1994 and 2006 puts the current net fiscal loss at around 1\% of GDP (Desai et al., 2009).

Among the potentially positive effects, one of the most enduring themes is the flow of remittances. Recent efforts to collect more comprehensive data indicate that remittances are even more important than previously thought. Remittance flows grew by a factor of five in real terms over the last two decades. In recent years the scale of North-south remittances has been equivalent to about half of foreign direct investment and double the amount of official development aid. For more than 20 countries with large emigrant diasporas the remittances amount to more than 10\% of GDP (Yang, 2011, p. 134). The literature on the macroeconomic impacts has followed the analysis of other inward capital flows, with a focus on country-level panel data. Clearly remittance flows can work through a variety of channels, including negative Dutch-disease effects or positive Keynesian effects, but much of the focus has been on domestic investment. The results have been mixed, and rather disappointing, perhaps reflecting differences in the underlying motives for remitting and the cross-country heterogeneity in the effects (Barajas et al., 2009; Rapoport and Docquier, 2006).

From the 1990s research turned to investigating the impact of the receipt of remittances at the household level-something that reflects the growing availability of source country micro-data. A key issue is the degree to which flows of remittances avert or relieve poverty among the households receiving them. Evidently remittances make a substantial difference in Latin America and in some African countries. To take one example Acosta et al. (2007, p.79) found that the poverty headcount (at under $\$ 2$ per day) is reduced by 2.1 percentage points in Mexico and 5.1 percentage points in El Salvador. But it is important to be clear about whether the counterfactual is no emigration or just no remittances. In the absence of the ability to remit, some emigrants would not go if it meant leaving the rest of the family in poverty. Although emigrants increase their incomes, in general they only remit a small fraction of those gains. As a result the remaining household may not be better off than it would be without a member having emigrated; this is the case for Mexico but not for El Salvador. Nevertheless, the household's income might be less volatile, as Stark (1991) suggested and as some empirical studies have found.

A further issue is whether remittances can be seen as in some sense promoting development. Much of the focus in recent work has been on whether remittances are invested in land, businesses, implements or other durables or if it is simply consumed. Mostly, it seems to have been used for consumption, but such estimates are vulnerable to endogeneity bias. Yang (2008) used the 1998 exchange rate shock to examine the effects of the increase in the real value of remittances to the Philippines. Most of the gain was used for investment although this partly reflects the temporary nature of the shock. Other studies have focused on the effects of remittances on the education and health 
of those left behind, particularly children (e.g. Acosta et al., 2007; Edwards and Ureta, 2003). As elsewhere the results have been mixed, and it is not always clear whether they are simply the effect of an increase in income or whether there is something special about income from remittances.

At a more macro level, a number of studies have examined the relationships between the size and location of emigrant diasporas and flows of trade and investment from the destination country to the origin. These have been explored for different sets of source and destination countries using gravity-style models, with the idea that expatriate communities either have preferences for home country goods or can reduce the costs of trade with the home country. The elasticities of imports or exports with respect to the migrant stock range from close to zero to 0.5 and these vary by country characteristics, classes of goods and types of migrant (Lodigiani, 2009, p. 30). Investment flows from rich host to poor(er) origin countries are also positively correlated with the size of the diaspora and especially with the share of high-skilled. As yet, it is difficult to assess the importance of diaspora effects on trade and investment overall, both because of the wide range of estimates and because of the lack of welfare analysis. Nevertheless such studies do point to the globalising role of diasporas through developing business networks and facilitating technology transfer.

An intriguing recent development is the study of the effects of diasporas on political and institutional structures in the home country. One might think that, by exercising the possibility of exit rather than voice, emigration of those with more human capital would lead to slower institutional improvement in source countries. But some studies have shown the opposite. Li and McHale (2009) find that a skilled diaspora is associated with weaker economic institutions but stronger political institutions in the home country. Although the mechanisms remain obscure, much of this probably occurs through return migration. In a fascinating study Spilimbergo (2009) shows that the more emigrants that acquire foreign university education in a democratic country the more democratic the source country becomes. But there may also be a downside; diasporas may support terrorism, criminal networks or trafficking in drugs or people. Those formed by refugees and dissidents may fund or foment civil wars in the home countries, either directly or through influencing host country governments (Salehyan and Gleditsch, 2006). Such issues have yet to be fully explored and absorbed into migration economics.

It is difficult to do justice to the diverse literature on the effects of diasporas on the origin country. As elsewhere data constraints are a limiting factor that is slowly being eased and the theory is gradually being refined. Progress has also been fostered by linking with the issues and methodology of development economics as well as by encroaching upon the agendas of other social sciences. Here, as elsewhere, the imperialism of economic methods into other social sciences accounts for at least part of its continued vitality. But as with other imperialisms insufficient account is often taken of the local culture.

\section{Conclusion}

In conclusion it is worth re-emphasising some of the key trends in research on international migration. These include the shift from a research agenda that was focused mainly on the effects of immigration to US and later to Europe, to one that is more global and diverse. While the topics and techniques were originally transposed from the US to other countries where immigration became a burning issue, research in and on those countries subsequently gained a momentum of its own. In the newer topics outlined above, European-based research is now at the forefront. At the same time there is a growing interest in countries outside the OECD, which is already beginning to spawn a new diaspora of ideas. This includes a shift in focus towards SouthSouth migration. Coupled with this is a distinct trend towards the diffusion of research at the micro level, which has fed on the availability of an increasingly rich and ever widening range of datasets. And as with other areas of economics, there is a focus on tighter links between theory and empirics. This is reflected in an increasing focus on endogeneity issues, which in turn has given rise in very recent years to the search for natural experiments and to experimental research designs.

So where should it go from here? In a provocative paper Clemens (2011, p. 99) suggests that issues like remittances and the brain drain are "a research agenda whose time has gone". His point is not that interest in these topics is flagging but that the effects they study are not economically important. The same could perhaps be said of the literatures on the assimilation and labour market impacts of immigration. Instead, he argues that the focus should be on the key elements that would help to produce better estimates of the global gains to free(er) international migration. At one level I have some sympathy with this view. For example, the literature on assimilation often assumes a rather pessimistic hue because it compares immigrants with similar workers at the destination and it potentially diverts attention away from the enormous gains realised by immigrants moving from poor to rich countries. Similarly, the literature on the diverse impacts of migration, both for destination and for source countries, tends to focus on the consequences for the stayers and not on the movers.

Clemens suggests that this is the result of a focus on welfare at the national level rather than at the international level. While there is some truth in this, there are also good reasons for it (and not just modern-day academic mercantilism as he implies). The global gains from migration are indisputably large and better measurement is unlikely to overturn that finding. But how can they be realised? Like it or not, the fact is that immigration policy is under the control of nation states and there are compelling reasons why this is unlikely to change (Hatton, 2007). As we have seen, in the rich countries where the easing of immigration policies would create the greatest gains, liberalisation is constrained by negative public attitudes. My reading of the literature over a quarter of a century is that the results have largely discredited people's worst fears about the threats from immigration. Thus immigrants do assimilate (even if slowly), the wage impacts are modest (even if underestimated), the fiscal impacts are not as dire as often supposed, and we have less need to feel guilty about the brain drain. Yet despite all the effort, academic researchers have failed to get this message across to society at large. In my view the pressing need is to better understand the political economy of immigration policy and then to use this knowledge to design immigration policies that would better overcome the popular resistance to freer migration.

\section{References}

Acosta, Pablo, Fanzylber, Pablo, Lopez, J. Humberto, 2007. The impact of remittances on poverty and human capital: evidence from Latin American household surveys. In: Özden, Çağlar, Schiff, Maurice (Eds.), International Migration, Economic Development and Policy. Palgrave Macmillan.

Adsera, Alicia, Pytlikova, Mariola, 2012. The role of language in shaping international migration. IZA Discussion Paper, p. 6333.

Alba, Richard, Nee, Victor, 1997. Rethinking assimilation theory for a new era of immigration. Int. Migr. Rev. 31, 826-874.

Barajas, Adolfo, Chami, Ralph, Fullenkamp, Connel, Gapen, Michael, Montiel, Peter, 2009. Do workers' remittances promote economic growth? IMF Working Paper WP/09/ 153.

Batista, Catia, Lacuesta, Aitor, Vicente, Pedro C., 2012. Testing the 'brain gain' hypothesis: micro evidence from Cape Verde. J. Dev. Econ. 97, 32-45.

Beine, Michel, Docquier, Frédéric, Rapoport, Hillel, 2001. Brain drain and economic growth: Theory and evidence. J. Dev. Econ. 64, 275-289.

Beine, Michel, Docquier, Frédéric, Rapoport, Hillel, 2008. Brain drain and human capital formation in developing countries: Winners and losers. Econ. J. 118, 631-652.

Belot, Michèle V., Hatton, Timothy J., 2012. Immigrant selection in the OECD. Scand. J. Econ. 14, 1105-1128.

Benhabib, Jess, 1996. On the political economy of immigration. Eur. Econ. Rev. 40, $1737-1743$

Bhagwati, Jagdish N., Hamada, Koichi, 1974. The brain drain international integration of markets for professionals and unemployment: a theoretical analysis. J. Dev. Econ. 1, $19-24$.

Boeri, Tito, 2010. Immigration to the land of redistribution. Economica 77 (651-487)

Borjas, George J., 1985. Assimilation, changes in cohort quality and the earnings of immigrants. J. Labor Econ. 3, 463-489.

Borjas, George J., 1987. Self-selection and the earnings of immigrants. Am. Econ. Rev. 77, 531-553. 
Borjas, George J., 1992. Ethnic capital and intergenerational mobility. Q. J. Econ. 107, 123-150.

Borjas, George J., 1995. Assimilation and changes in cohort quality revisited: what happened to immigrant earnings in the 1980s? J. Labor Econ. 13, 201-245.

Borjas, George J., 2003. The labor demand curve is downward sloping: reexamining the impact of immigration on the labor market. Q. J. Econ. 118, 1335-1374.

Borjas, George J., 2006. Native internal migration and the labor market impact of immigration. J. Hum. Resour. 41, 221-258.

Borjas, George J., 2008. Labor outflows and labor inflows in Puerto Rico. J. Hum. Cap. 2, 32-67.

Borjas, George J., Bratsberg, Bernt, 1996. Who leaves? The out-migration of the foreign born. Rev. Econ. Stat. 78, 65-76.

Card, David, 1990. The impact of the Mariel Boatlift on the Miami labor market. Ind. Labor Relat. Rev. 43, 247-257.

Card, David, 2001. Immigrant inflows, native outflows, and the local labor market impacts of higher immigration. J. Labor Econ. 19, 22-64.

Card, David, 2005. Is the new immigration really so bad? Econ. J. 115, F300-F323.

Card, David, Dustmann, Christian, Preston, Ian, 2012. Immigration wages and compositional amenities. J. Eur. Econ. Assoc. 10, 78-119.

Carrington, William J., di Lima, Pedro J.F., 1996. The impact of 1970s repatriates from Africa on the Portuguese labor market. Ind. Labor Relat. Rev. 49, 330-347.

Casey, Teresa, Dustmann, Christian, 2010. Immigrants' identity, economic outcomes and the transmission of Identity across generations. Econ. J. 120, F31-F51.

Chand, Satish, Clemens, Micheal A., 2008. Skilled emigration and skill creation: a quasiexperiment. Center for Global Development Working Paper, p. 152.

Chiquiar, Daniel, Hanson, Gordon H., 2005. International migration, self-selection, and the distribution of wages: evidence from Mexico and the United States. J. Polit. Econ. 113, 239-281.

Chiswick, Barry R., 1978. The effect of Americanization on the earnings of foreign-born men. J. Polit. Econ. 86, 897-921.

Chiswick, Barry R., Miller, Paul W., 1995. The endogeneity between language and earnings: international analyses. J. Labor Econ. 13, 246-288.

Clark, Ximena, Hatton, Timothy J., Williamson, Jeffrey G., 2007. Explaining U.S. immigration, 1971-1998. Rev. Econ. Stat. 89, 359-373.

Clemens, Michael A., 2011. Economics and emigration: trillion dollar bills on the sidewalk. J. Econ. Perspect. 25, 83-106.

Clemens, Michael A., Montenegro, Claudio E., Pritchett, Lant, 2008. The place premium: wage differences for identical workers across the US border. World Bank Policy Research Working Paper, p. 4671.

Constant, Amelie, Zimmermann, Klaus F., 2008. Measuring ethnic identity and its impact on economic behaviour. J. Eur. Econ. Assoc. 6, 424-433.

Coulombe, Serge, Tremblay, Jean-François, 2009. Migration and skills disparities across the Canadian provinces. Reg. Stud. 43, 5-18.

Desai, Mihir A., Kapur, Devesh, McHale, John, Rogers, Keith, 2009. The fiscal impact of high-skilled emigration: flows of Indians to the U.S. J. Dev. Econ. 88, 32-44.

Docquier, Frédéric, Marfouk, Abdeslam, 2006. International migration by education attainment, 1990-2000. In: Özden, Cağlar, Schiff, Maurice (Eds.), International Migration, Remittances, and the Brain Drain. Washington D.C., World Bank, pp. 151-199.

Docquier, Frédéric, Rapoport, Hillel, 2012. Globalization, brain drain, and development. J. Econ. Lit. 50, 681-730.

Drinkwater, Stephen, Levine, Paul, Lotti, Emanuela, Pearlman, Joseph, 2003. The economic impact of migration: a survey. Economics Discussion Paper 0103. University of Surrey.

Dustmann, Christian, 1997. Return migration, uncertainty and precautionary savings. J. Dev. Econ. 52, 295-316.

Dustmann, Christian, Preston, Ian, 2001. Attitudes to ethnic minorities, ethnic context and location decisions. Econ. J. 111, 353-373.

Dustmann, Christian, Preston, Ian, 2007. Racial and economic factors in attitudes to immigration. Berkeley Electron. J. Econ. Anal. Policy 7 ((Advances), Art 62).

Dustmann, Christian, van Soest, Arthur, 2001. Language fluency and earnings: estimation with misclassified language indicators. Rev. Econ. Stat. 83, 663-674.

Dustmann, Christian, Fadlon, Itzham, Weiss, Yoram, 2011. Return migration, human capital accumulation and the brain drain. J. Dev. Econ. 95, 58-67.

Dustmann, Christian, Frattini, Tomaso, Preston, Ian, 2012. The effect of immigration along the distribution of wages. Rev. Econ. Stat. 80, 145-173.

Edwards, Alejandra C., Ureta, Manuelita, 2003. International migration, remittances and schooling: evidence from El Salvador. J. Dev. Econ. 72, 429-461.

Facchini, Giovanni, Mayda, Anna Maria, 2009. Does the welfare state affect individual attitudes toward immigrants? Rev. Econ. Stat. 91, 295-314.

Facchini, Giovanni, Mayda, Anna Maria, Mishra, Prachi, 2011. Do interest groups affect US immigration policy? J. Int. Econ. 85, 114-128.

Freeman, Gary P., 1995. Modes of immigration politics in liberal democratic states. Int Migr. Rev. 29, 881-902.

Gibson, John, McKenzie, David, 2012. The economic consequences of 'brain drain' of the best and brightest: Microeconomic evidence from five countries. Econ. J. 122, 339-375.

Greenaway, David, Nelson, Douglas, 2006. The distinct political economies of trade and migration policy: Through the window of endogenous policy models. In: Fodors, Federico, Langhammer, Rolf J. (Eds.), Labor Mobility and the World Economy. Springer, Berlin, pp. 295-327.
Grogger, Jeffrey, Hanson, Gordon, 2011. Income maximization and the selection and sorting of international migrants. J. Dev. Econ. 95, 42-57.

Hainmueller, Jens, Hiscox, Michael J., 2007. Educated preferences: explaining individua attitudes toward immigration in Europe. Int. Organ. 61, 399-442.

Hainmueller, Jens, Hiscox, Michael J., 2010. Attitudes towards highly skilled and lowskilled immigration: evidence from a survey experiment. Am. Polit. Sci. Rev. 104 61-84.

Hatton, Timothy J., 2007. Should we have a WTO for international migration? Econ. Policy $50,339-383$.

Hatton, Timothy J., 2009. The rise and fall of asylum: what happened and why? Econ. J 119, F183-F213.

Hatton, Timothy J., Williamson, Jeffrey G., 2005. Global Migration and the World Economy. MIT Press, Cambridge Mass.

Hunt, Jennifer, 1992. The impact of the 1962 repatriates from Algeria on the French labor market. Ind. Labor Relat. Rev. 45, 556-572.

Kessler, Alan E., Freeman, Gary P., 2005. Support for extreme right-wing parties in Western Europe: individual attributes, political attitudes, and national context. Comp. Eur. Polit. 3, 261-288.

Lahav, Gallya, 2004. Public opinion toward immigration in the European Union: does it matter? Comp. Polit. Stud. 37, 1151-1183.

Li, Xiaoyang and John McHale, 2009. Emigrants and Institutions. Unpublished paper, University of Michigan.

Lodigiani, Elisabetta, 2009. Diaspora externalities as a cornerstone of the new brain drain literature. Centro Studi Luca D'Agliano Development Studies Working Paper, p. 277.

Longhi, Simonetta, Nijkamp, Peter, Poot, Jacques, 2005. A Meta-analytic assessment of the effect of immigration on wages. J. Econ. Surv. 19, 451-477.

Manacorda, Marco, Manning, Alan, Wadsworth, Jonathan, 2012. The impact of immigration on the structure of male wages: theory and evidence from Britain. J. Eur. Econ. Assoc. 10, 120-151.

Mattoo, Aaditya, Neagu, Ileana Cristina, Özden, Cağlar, 2008. Brain waste? Educated immigrants in the US labor market. J. Dev. Econ. 87, 255-269.

Mayda, Anna Maria, 2010. International migration: a panel data analysis of the determinants of bilateral flows. J. Popul. Econ. 23, 1249-1274.

Mayr, Karin, Peri, Giovanni, 2009. Brain drain and brain return: theory and application to eastern-western Europe. B.E. J. Econ. Anal. Policy 9 ((Contributions), Art 49).

Mishra, Prachi, 2007. Emigration and wages in source countries. J. Dev. Econ. 82, 180-199.

Mountford, Andrew, 1997. Can a brain drain be good for growth in the source economy? J. Dev. Econ. 53, 287-303.

Munshi, Kaivan, 2003. Networks in the modern economy: Mexican migrants in the U. S. labor market. Q. J. Econ. 118, 549-599.

OECD, 2008. International Migration Outlook. OECD, Paris.

O'Rourke, Kevin H., Sinnott, Richard, 2006. The determinants of individual attitudes towards immigration. Eur. J. Polit. Econ. 22, 838-861.

Ortega, Francesc, Peri, Giovanni, 2012. The effect of income and immigration policies on international migration. Boston NBER Working Paper. NBER, p. 18322.

Ottaviano, Gianmarco I.P., Peri, Govanni, 2012. Rethinking the effects of immigration on wages. J. Eur. Econ. Assoc. 10, 152-197.

Peri, Giovanni, Sparber, Chad, 2009. Task specialization, immigration and wages. Am. Econ. J. Appl. Econ. 1, 135-169.

Peri, Giovanni, Sparber, Chad, 2011. Assessing inherent model bias: an application to native displacement in response to immigration. J. Urban Econ. 69, 82-91.

Rapoport, Hillel, Docquier, Frédéric, 2006. The Economics of Migrants' Remittances. In: Kolm, S., Ythier, J.M. (Eds.), Handbook of the Economics of Giving, Altruism and Reciprocity. vol. 2. Elsevier, Amsterdam, North Holland.

Salehyan, Idean, Gleditsch, Kristian Skrede, 2006. Refugees and the spread of civil war. Int Organ. 60, 335-366.

Scheve, Kenneth F., Slaughter, Mathew J., 2001. Labor market competition and individual preferences over immigration policy. Rev. Econ. Stat. 83, 133-145.

Smith, James P., Edmonston, Barry, 1997. The New Americans: Economic, Demographic and Fiscal Effects of Immigration. National Academies Press, Washington DC

Spilimbergo, Antonio, 2009. Democracy and foreign education. Am. Econ. Rev. 99, 528-543.

Stark, Oded, 1991. The Migration of Labor. Blackwell, London.

Stark, Oded, Helmenstein, Christian, Prskawetz, Alexia, 1997. A brain gain with a brain drain. Econ. Lett. 55, 227-234.

Storesletten, Kjetil, 2000. Sustaining fiscal policy through immigration. J. Polit. Econ. 108 300-324.

Storesletten, Kjetil, 2003. Fiscal implications of immigration-a net present value calculation. Scand. J. Econ. 105, 487-506.

Trefler, Daniel, 1998. Immigrants and natives in general equilibrium trade models. In: Smith, James P., Edmonston, Barry (Eds.), The Immigration Debate: Studies on the Economic, Demographic, and Fiscal Effects of Immigration. National Academy Press, Washington DC.

Van Dalen, Hendrik P., Groenewold, George, Schoorl, Jeanette J., 2005. Out of Africa: what drives the pressure to emigrate? J. Popul. Econ. 18, 741-778.

Yang, Dean, 2008. International migration, remittances and household investment: evidence from Philippine migrants' exchange rate shocks. Econ. J. 118, 592-630.

Yang, Dean, 2011. Migrant remittances. J. Econ. Perspect. 25, 129-152. 